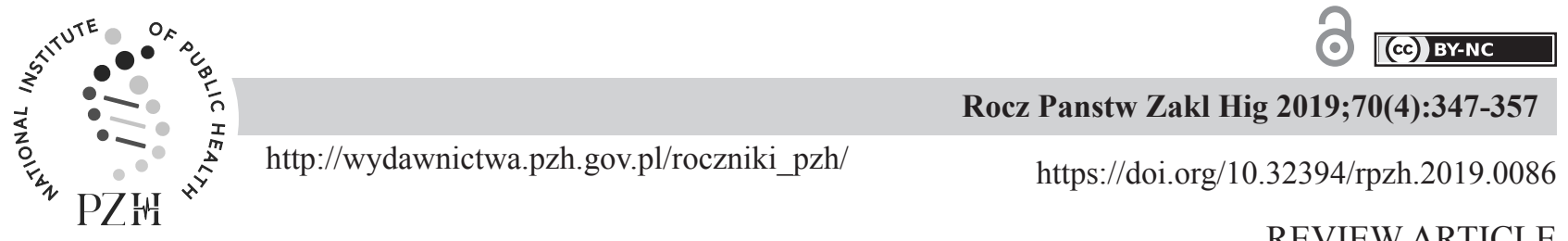

\title{
FOOD GROUPS IN DIETARY PREVENTION OF TYPE 2 DIABETES
}

\author{
Alicja Basiak-Rasałal, Dorota Różańska², Katarzyna Zatońskal \\ ${ }^{1}$ Wroclaw Medical University, Department of Social Medicine, Bujwida str. 44, Wrocław, Poland \\ ${ }^{2}$ Wroclaw Medical University, Department of Dietetics, Parkowa str. 34, Wrocław, Poland
}

\begin{abstract}
According to the World Health Organization diabetes will be the seventh leading cause of death worldwide in 2030. Majority of diabetic patients suffer from type 2 diabetes (T2DM), which is mostly avoidable. The most important modifiable risk factors of type 2 diabetes are: overweight and obesity, improper diet, sedentary lifestyle and tobacco smoking. Even in prediabetic state, improving diet and physical activity can slow down or even stop progression to diabetes. In the view of health burden of diabetes it is essential to thoroughly investigate the risk factors and develop more specific preventive strategies. Recently published studies focus on food groups rather than individual products to assess the link between nutrition and risk of type 2 diabetes. Identifying food groups of possible beneficial and deleterious effect on the risk of type 2 diabetes could facilitate the dietary counselling. The aim of the overview is to summarize the possible association between consumption of food groups on the risk of type 2 diabetes on the basis of available literature. Observations from studies and meta-analyses indicate on an inverse association between consumption of fresh vegetables and fruit, whole grains, lean dairy, fish, nuts and the risk of type 2 diabetes. Food groups that seemed to increase the risk of type 2 diabetes are: red and processed meat, refined grains, sugar-sweetened beverages. It is important to note, that no individual nutrients, but diverse dietary pattern, composed of every recommended food group in adequate amounts can contribute to healthy lifestyle and T2DM prevention.
\end{abstract}

Key words: diabetes, diet, prevention, risk of diabetes, dietary prevention of diabetes

\section{STRESZCZENIE}

Według Światowej Organizacji Zdrowia (WHO) do 2030 roku cukrzyca stanie się siódmą z kolei przyczyną zgonów na świecie. Większość pacjentów cierpi na cukrzycę typu 2, której podłoże jest w dużej mierze modyfikowalne. Najważniejszymi modyfikowalnymi czynnikami ryzyka cukrzycy są: nadwaga i otyłość, nieprawidłowa dieta, brak aktywności fizycznej oraz palenie tytoniu. Wprowadzenie interwencji w zakresie poprawy sposobu żywienia oraz zwiększenia aktywności fizycznej wśród pacjentów ze stanem przed cukrzycowym może spowolnić lub nawet zatrzymać progresję do pełnoobjawowej cukrzycy typu 2. Z powodu ogromnego zagrożenia dla zdrowia publicznego, którego przyczyną jest stały wzrost zachorowań na cukrzycę, istnieje konieczność badania czynników ryzyka w celu opracowania skutecznych programów zdrowotnych. Niedawno publikowane badania analizujące związek pomiędzy żywieniem a cukrzycą typu 2, skupiają się na grupach produktów, a nie na pojedynczych składnikach pokarmowych. Identyfikacja korzystnych oraz potencjalnie szkodliwych grup produktów wpływających na ryzyko cukrzycy typu 2 może okazać się bardzo pomocna w poradnictwie zdrowotnym. Celem artykułu przeglądowego jest podsumowanie zależności pomiędzy spożywaniem poszczególnych grup produktów a ryzykiem cukrzycy typu 2 w świetle aktualnej literatury naukowej. Do grup produktów, które w badaniach oraz metaanalizach powiązane są z niższym ryzykiem cukrzycy typu 2 należą: warzywa i owoce, pełnoziarniste produkty zbożowe, chudy nabiał, ryby oraz orzechy. Do grup produktów, które powiązane są z wyższym ryzykiem cukrzycy typu 2 należą: czerwone oraz przetworzone mięso, produkty zbożowe z oczyszczonego ziarna, słodzone napoje. Należy zaznaczyć, że nie pojedyncze składniki pokarmowe lecz zróżnicowana dieta, składająca się z zalecanych grup produktów w odpowiednich ilościach przyczynia się do prewencji cukrzycy typu 2.

Słowa kluczowe: cukrzyca, dieta, zapobieganie cukrzycy, ryzyko cukrzycy

Corresponding author: Alicja Basiak-Rasała, Wroclaw Medical University, Department of Social Medicine, Bujwida 44, 50-345 Wroclaw, Poland, tel/fax +48 7132821 45, e-mail: alicja.basiak-rasala@umed.wroc.pl

(C) Copyright by the National Institute of Public Health - National Institute of Hygiene 


\section{INTRODUCTION}

According to the World Health Organization (WHO), the most important modifiable risk factors of type 2 diabetes are: overweight and obesity, improper diet, sedentary lifestyle and tobacco smoking[1]. Recently published meta-analysis focus on food groups rather than individual products to assess the link between nutrition and risk of type 2 diabetes development[2]. According to the WHO improper diet is responsible for $4.6 \%$ of disability-adjusted life years (DALY), whereas overweight and sedentary lifestyle for next $3.7 \%$ and $1.4 \%$, respectively[3]. Prevalence of diabetes increased over two-fold since the 80 's of XX century, from $4.6 \%$ of adult population in 1980 to $8.5 \%$ in 2014 [1]. Diabetes caused approximately $1.6 \mathrm{mln}$ deaths worldwide in 2015, but it is estimated that high blood glucose could contribute to next $2.2 \mathrm{mln}$ deaths related to i.e. cardiovascular diseases[1]. Impaired fasting glucose and impaired glucose tolerance preceding full-symptomatic type II diabetes are regarded independent risk factors for cardiovascular diseases[4], although in recently published metaanalyses this association is not as strong as in the case of full-symptomatic diabetes[5]. The conditions of impaired fasting glucose or impaired glucose tolerance don't necessarily mean inevitable progression to type II diabetes. Despite present disorders of carbohydrate metabolism, improving diet and physical activity can slow down or even stop progression to diabetes[6]. In the view of health burden of diabetes it is essential to thoroughly investigate the risk factors and develop more specific preventive strategies. Identifying food groups of possible beneficial and deleterious effect on the risk of type 2 diabetes could facilitate the dietary counselling. Literature databases including Scopus (https://www.scopus.com) and PubMed (https://www. ncbi.nlm.nih.gov/pubmed/) were searched. Search terms used: "type 2 diabetes" OR "diabetes" OR "hyperglycemia" and terms related to food groups ("cereals", "grain", "vegetables", "fruit", "dairy", "fish", "meat", "red meat", "processed meat", "eggs", "poultry", "fats", "oill", "nuts", "sugar-sweetened beverages"). Search was limited to the literature in English language. Additionally, the references of withdrawn articles were searched. If available, randomized studies, prospective and cohort studies in human population, published no earlier than in 2008 were prioritized. Well-conducted meta-analyses were also included in the search. The aim of hereby overview is to summarize the possible association between consumption of individual food groups on the risk of type 2 diabetes on the basis of available literature.

\section{Cereals}

Dietary guidelines for diabetic patients [7], recommend increasing the consumption of whole grain products at the expense of refined grains. Whole grains in the contrary to refined grains are rich source of dietary fiber, resistant starch and various vitamins and minerals. Meta-analysis of 17 cohort studies performed by Yao et al. [8] indicates that increased consumption of dietary fiber decreases the risk of type 2 diabetes. According to Wirström et al.[9] consumption of whole-grain products decreases the risk of prediabetes. Chanson-Rolle et al.[10] in meta-analysis of prospective studies estimated that increasing the intake of whole-grain products up to 45 $\mathrm{g} / \mathrm{d}$ would lower the risk of type 2 diabetes by $20 \%$. As a matter of fact, the consumption of whole-grain products in so-called "western diet" is rather low: in the USA $72 \%$ of Americans, at the age of $19-50$ years and $66 \%$ of those at the age of 50 years and older consume less than 0.6 serving (about $10.5 \mathrm{~g} / \mathrm{d}$ ) of whole-grain products daily[11]. Meta-analysis conducted by Nettleton et al. [12] concluded that every additional serving of whole-grain products daily is associated with lower glucose concentration by 0.019 units and insulin concentration by 0.021 units. It is speculated that not only resistant starch and fiber present in whole-grain products are responsible for lowering the risk of type 2 diabetes, but also other compounds, such as: phytic acid, magnesium, zinc, calcium, selenium, tocopherols, phenolic acids, flavonoids, betaine, inositols and saponins[13]. It has been observed in human studies, that resistant starch improves glycemic control, but the exact mechanism is still an object of debate. Resistant starch, unlike regular starch, is not susceptible to digestion in stomach and small intestine, but is fermented by bacteria when it reaches large colon [14]. The main products of resistant starch's breakdown are short-chained fatty acids (SCFA), such as acetate, propionate and butyrate. Products containing resistant starch are not only slowly digested, which leads to slower glucose release, but it is speculated that also SCFA, as a product of fermentation, influence glucose homeostasis in liver and muscles[15].

Dietary carbohydrates have the largest effect on postprandial glucose among macronutrients. Several decades ago the concept of Glycemic Index (GI) was introduced to rank the foods according to their postprandial glucose response[16]. Glycemic response after glucose consumption is considered reference value and equals a GI of 100 . Soon after the concept of Glycemic Load (GL) was established, which combines the GI and amount of carbohydrates in the product. Glycemic response after consumption of carbohydrate product can be differentiated i.a. by starch composition, content of dietary fiber, simple 
sugars, protein and fat content, processing, time of storage and harvest[17]. Whole-grain cereals, like rye bread, oatmeal, durum pasta, brown rice have low GI $(<55)$, which reflects also their slower rate of digestion and absorption; whereas products of refined wheat, white rice, confectionery have high GI $(>70)[18]$, which reflects their rapid digestion and absorption. According to study by Bhupathiraju et al.[19], who analyzed data from three large prospective cohort studies, participants who consumed diets of high GI or GL and low cereal fiber had $40 \%$ higher risk of T2DM than those whose diets were characterized by low GI, GL and high fiber. On the other hand, results from other studies focusing on association between GI, GL and risk of type 2 diabetes are inconsistent. It is speculated that the association can be gender-specific. In studies in women, there was observed that low-GI diet was associated with lower risk of type 2 diabetes $[20,21]$, whereas in large randomized study in men GI or GL were not associated with type 2 diabetes risk [22]. Although there is no global consensus on dietary guidelines in diabetes management, there are evidence from randomized controlled trials that diabetic patients can benefit from low-GI diets. In study by Jenkins et al. [23] low-GI diet over 6-month period in type 2 diabetic participants resulted in lower $\mathrm{HbAlc}$ levels and higher HDL levels in blood. In randomized study by Gomes et al. [24], low-GI diet over 1-month period in type 2 diabetic participants resulted in slightly reduced inflammatory response (by lower levels of IL-6 mRNA and TNF- $\alpha$ mRNA expressions) and reduced body fat. Randomized study by $\mathrm{Ma}$ et al.[25] also indicates that low-GI diet can be an alternative to American Diabetic Association (ADA) dietary guidelines in diabetes management, as it was just as good in controlling HbAlc levels with concomitant less diabetic medication than in participants with ADA diet.

\section{Dairy products}

Dairy is a vast group of products and diverse in composition and nutritional value. All dairy products derive from milk. According to the meta-analysis conducted by Tong et al. [26], participants, who were characterized by the highest consumption of milk and dairy products had lower risk of the development of type 2 diabetes by $14 \%$ in comparison to those participants, who consumed less dairy products. The same authors concluded that inverse correlation between consumption of dairy products and risk of type 2 diabetes, was only observed in the case of skimmed milk and low-fat dairy products - such association was not confirmed in the case of full-fat dairy products. It is speculated that high content of calcium and vitamin $\mathrm{D}$ are responsible for lowering the risk of type
2 diabetes in mechanism of modulating the function of pancreatic beta-cells, increasing insulin sensitivity and decreasing systematic inflammation by influencing cytokine excretion [27]. On the other hand, in Women's Health Study [28], the researchers observed the inverse association between the consumption of dairy products and risk of type 2 diabetes, independently from other factors, such as: intake of vitamin D, calcium and magnesium. It is speculated that not only vitamin $\mathrm{D}$ and calcium, but also other nutrients present in milk and dairy products play a role in regulation of carbohydrate metabolism, e.g. dairy proteins. There are some evidence, that whey protein can be associated with improved insulin sensitivity [29]. In study by Ryan et al., intraduodenal infusion of whey proteins, in loads resembling natural pace, resulted in increased release of cholecystokinin and glucagon-like peptide 1 (GLP1) and increased pyloric motility[30]. According to the findings from Nurse's Health Study II [31], increased intake of dairy products in developmental age in women was associated with decreased risk of type 2 diabetes in middle age. In Epic-InterAct Study[32] the consumption of total dairy was not associated with risk of type 2 diabetes, but if adjusted for types of dairy products, the consumption of fermented dairy products (cheese, yoghurt, thick fermented milk) was in fact inversely associated with risk of type 2 diabetes. Similar association was observed in three large US cohort studies. Although the consumption of total dairy was not associated with risk of type 2 diabetes, there was observed a significant inverse association between consumption of yoghurt and risk of T2DM [33]. Same authors concluded that every additional serving of yoghurt per day was associated with 18\% lower risk of T2DM. Yoghurt is abundant source not only of calcium, magnesium and vitamin $\mathrm{D}$, but also conjugated linoleic acid and probiotics. In addition, fermentation increases dietary value of yoghurt in comparison to milk, as fermentation can improve the bioavailability of some micronutrients, like calcium, magnesium and vit. B12 [34]. It is speculated that probiotics can play an important role in modulating the risk of T2DM. In double-blind, randomized study by Kassaian et al.[35], the group supplemented with symbiotic (a mix of probiotic and prebiotic) in comparison to placebo, was characterized by improved fasting plasma glucose and insulin levels, improved glycated hemoglobin levels and insulin sensitivity (assessed by HOMA-IR index). The exact mechanism underlying the association between consumption of probiotics and glycemic control remain unclear. The composition of macro- and micronutrients vary from one dairy product to another. Analysis of impact of total dairy on the risk could be misleading. Dietary guidelines emphasizes that not only healthy people, but also diabetic patients should consume 2-3 servings 
of low-fat dairy products, like skimmed milk, yoghurt and other fermented dairy products $[7,36,37]$.

\section{Meat, fish, eggs}

According to dietary guidelines, a food group including meat, fish and eggs (MF\&E) shouldn't be consumed in amounts exceeding 1 serving per day $(100-150 \mathrm{~g})$ [36, 37]. Additionally, it is advised, that $1-2$ times a week, a serving of MF\&E should be replaced by a serving of legumes. MF\&E are an abundant source of highly bioavailable protein, iron and vitamin B12 [36]. Dietary guidelines for management of adults with diabetes by American Diabetes Association (ADA) emphasizes, that recommendations for intake of MF\&E for diabetic patients don't differ significantly from recommendations for general population. Diabetic patients are advised to choose leaner meats (e.g. poultry) over red meat and to choose leaner protein alternatives more often (e.g. legumes) [38]. In the study by $\mathrm{Ke}$ et al., higher intake of protein from plant sources (e.g. legumes) was associated with decreased risk of T2DM, on the contrary to higher intake of protein from animal sources (e.g. red meat)[39]. Same authors emphasized the importance of focusing on dietary patterns, rather than individual macronutrients. According to Feskens et al.[40] the intake of red and processed meat significantly increases the risk of type 2 diabetes. In the randomized cross-over study conducted by Kim et al.[41] among overweight participants; participants with impaired fasting glucose or impaired glucose tolerance; the diet rich in red and processed meat and refined grains applied for 4 weeks, significantly increased insulin resistance in comparison to the diet rich in whole-grain products, skimmed dairy products, legumes and nuts. It was estimated that improving dietary habits by the patients at risk of developing of type 2 diabetes was associated with $50 \%$ increase of insulin sensitivity after merely the month of diet [41]. Researchers didn't observe changes in insulin sensitivity after implementing the diet in healthy subjects (without disorder of carbohydrate metabolism or insulin resistance). In the cross-sectional study by Zelber-Sagi et al. [42] total consumption of meat, but particularly red and processed meat was associated not only with increased risk of insulin resistance, but also non-alcoholic fatty liver disease, even after adjusting the analysis to Saturated Fatty Acids (SFA) and cholesterol content. Meat is a source of SFA and dietary cholesterol, but neither total dietary SFA [43], nor dietary cholesterol [44] have been associated with increased risk of T2DM in recent studies. Those conclusions were contrary to results obtained in the study by Guess et al. [45] in which researchers compared the intake of fatty acids between normoglycaemic participants, prediabetes participants and participants with type 2 diabetes, and provided observation that increased consumption of saturated fatty acids was associated not only with higher risk of impaired fasting glucose and higher concentration of glucose after $2 \mathrm{~h}$ in OGTT (Oral Glucose Tolerance Test), but also with insulin resistance. Moreover, higher consumption of transunsaturated fatty acids increases the risk of impaired glucose tolerance after $2 \mathrm{~h}$ in OGTT, while increased consumption of polyunsaturated fatty acids (regardless of type) improves glucose tolerance, as well as the peripheral insulin sensitivity. There is a possibility that not the individual types of fatty acids, but in fact their dietary sources and other components can play a major role in modulating the risk of T2DM. Study by Wanders et al. [46] provided no association between intake of SFA, MUFA, PUFA and trans unsaturated fatty acids (TFA) and markers of T2DM (fasting and postprandial blood glucose and insulin, HOMA-IR and HOMA-B). Interestingly, stratification by dietary sources revealed that fatty acids originating from meat were positively associated with insulin resistance and secretion, but no such association was observed in case of fatty acids originating from dairy and plant sources, providing a conclusion that association between fatty acids and risk of T2DM may be dependent on dietary sources [46]. Results from Framingham Offspring Study indicated, that although total dietary cholesterol was not associated with increased risk of T2DM or impaired fasting glucose, in contrast, higher intake of fish, whole-grain products and fiber were associated with lower risk of T2DM [44]. Red and processed meat are also a source of heme iron, heterocyclic amines (HCAs) and nitrates, the excess of which can play role in deterioration of glucose metabolism[47], though in case of HCAa and nitrates, the evidence come mostly from animal studies [48, 49]. The way, the meat is prepared also play a role in modulating the risk of T2DM. Processing meat (both red meat and chicken) on the open-flame and/or in high temperatures, like grilling/barbecuing/broiling was associated with increased risk of T2DM [50]. According to the findings from 25 years of observation in prospective study CARDIA [51] consumption of n-3 polyunsaturated fatty acids and fish (excluding fried fish) was associated with significantly lower risk of metabolic syndrome, impaired fasting glucose and impaired glucose tolerance. In Norwegian NOWAC study [52] researchers observed inverse association between consumption of lean fish and risk of type 2 diabetes. Interestingly, in literature, studies focused mostly on fatty saltwater fish, as richer source of n-3 polyunsaturated fatty acids than lean fish, and their protective role on the risk of metabolic syndrome. It is speculated, that lower content of contamination in lean fish, including heavy metals and higher content 
of taurine (amino acid of potentially beneficial effect on the risk of metabolic syndrome and type 2 diabetes) than fatty saltwater fish can play role in understanding this association[52]. Interestingly, increasing fish consumption in the diet can be beneficial for management of T2DM complications. According to Chua et al. [53], increased fish consumption was inversely associated with severity of diabetic retinopathy, moreover, increased consumption of fish among diabetic patients without retinopathy was associated with wider retinal vascular caliber. Fish are an important dietary source of $\omega-3$ polyunsaturated fatty acids ( $\omega-3$ PUFA) [36]. Increased consumption of $\omega-3$ PUFA with the diet, but also lower ratio of $\omega-6 / \omega-3$ fatty acids in the diet has been associated with lower risk of T2DM [54]. Moreover, in meta-analysis of randomized controlled trials by O'Mahoney et al., higher intake of $\omega$-3 PUFA was associated not only with lower HbA1c levels, but also with lower levels of TNF- $\alpha$ and IL- 6 , inflammatory cytokines, which can contribute to vascular complications in T2DM [55]. According to the mentioned CARDIA study [51], increased consumption of n-3 PUFA was associated with lower risk of impaired fasting glucose and impaired glucose tolerance. On the contrary, $W u$ et al. [56] in a meta-analysis of 16 observational studies did not confirm neither positive nor negative influence of $\omega-3$ PUFA (in this case combination of eicosapentaenoic acid (EPA) and docosahexaenoic acid (DHA)) on the risk of T2DM. Similarly, more recent meta-analysis failed to provide significant association between consumption of $\omega-3$ PUFA and levels of $\mathrm{HbA1c}$ [57]. It is possible that influence of n-3 PUFA on risk of type 2 diabetes can be dependent of sex. According to a meta-analysis conducted by Abbott et al. [58], the consumption of n-3 PUFA was associated with lower risk of insulin resistance, but only in women, while in men such association was not observed.

Meta-analysis of prospective cohort studies conducted by Tamez et al. [59] concluded, that consumption of eggs is associated with higher risk of type 2 diabetes. On the other hand, the strongest correlation was observed in American cohort, but such association was not observed in other countries. Such observation could be explained by differences in composition of eggs between countries or other, country-specific factors in diet [59]. Wallin et al. [60] presented the same conclusion: during the Swedish cohort study (The Cohort if Swedish Men conducted in years 1998-2012 in group of 39610 men) there was no association observed between consumption of eggs and risk of type 2 diabetes, but in conducted metaanalysis the association was observed only in cohorts from the USA.

\section{Fats/oils}

Analyzing an influence of fat, as an independent food group, on carbohydrate metabolism is rather complicated, because of heterogeneity of fats and differences in metabolic effects of individual fatty acids. Dietary fats are defined as every lipid, of animal or plant origin, consumed with food [61]. Dietary fat can be introduced in visible form of oils, butter or lard or as a constituent of other products, like meat, dairy, eggs etc. Since the influence of fatty acids as constituents of meat, fish and eggs have been elaborated in previous paragraph, this section will be focusing on oils.

Vegetable oils, as a source of unsaturated fatty acids and vitamin E, are a recommended replacement for dietary sources of SFA, e.g. butter and lard, both in general population and diabetic patients[36-38]. Vegetable oils differ from one another regarding their composition and properties. Olive oil is a rich source not only of MUFA, but also bioactive compounds, like oleuropein and hydroxytyrosol, which have been hypothesized to have antihyperglycemic and antioxidant effect [62]. Oleuropein and hydroxytyrosol administered to diabetic rats were associated with decreased serum glucose and improvement of oxidative stress parameters[63]. Higher adherence to Mediterranean Diet, characteristic for high intake of olive oil, fish, fruit, vegetables and wholegrains has been associated with lower risk of metabolic syndrome, including impaired glucose metabolism [64]. Results from 22 years of observation in Nurses' Health Study indicate, that in women, increased consumption of olive oil was associated with lower risk of developing T2DM [65]. Rapeseed oil, which consists of $72.8 \%$ of MUFAs, $20.9 \%$ of PUFAs and only $6.3 \%$ of SFA [66], along with olive oil is recommended vegetable oil [36, 37]. In a small, but randomized study by Nigam et al.[67] in men with non-alcoholic fatty liver disease, participants were divided into three groups receiving daily over the period of 6-months: 1) olive oil; 2) rapeseed oil and 3) other commonly used oils (mostly safflower). Authors observed that in olive oil group in comparison to rapeseed oil group and control, fasting insulin levels and HOMA-IR were significantly lower. Moreover, while comparing the results pre- and postintervention, authors observed that in rapeseed oil group, level of fasting blood glucose significantly decreased[67]. There are fewer studies focusing on association between risk of T2DM and consumption of n-3 PUFA from plant sources (predominantly with flaxseed oil) than from marine sources. According to $W u$ et al. [56] dietary consumption of $\alpha$-linolenic acid (ALA) is modestly associated with decreased risk of T2DM. The richest plant source of ALA is flaxseed oil [68]. In randomized, double-blind study by Bloedon et 
al. [69], addition of flaxseed to the diet of participants, resulted in improved insulin sensitivity (HOMA-IR index lowered by $23.7 \%$ ).

\section{Fruit and vegetables}

Fruit and vegetables are considered some of the most healthy dietary products. Dietary guidelines recommend to consume at least $400 \mathrm{~g}$ of fruit and vegetables a day $[37,61]$. Mediterranean diet, which is rich in mono- and polyunsaturated fatty acids, but also fruit and vegetables is considered highly effective in prevention of cardiovascular diseases and metabolic syndrome [64]. Both fruit and vegetables are not only the source of the dietary fiber, but also antioxidative vitamins, flavonoids and minerals, which can contribute to their beneficial effect [61]. In the study conducted by Sotoudeh et al. [70] dietary total antioxidant capacity (DTAC) was associated with lower risk of prediabetes and fruits and vegetables were the most prevalent sources of antioxidant compounds in the diet of analyzed participants. Oxidative stress is one of the possible factors contributing to deterioration of glucose metabolism. Diet rich in flavonoids and other polyphenols have been associated with decreased risk of T2DM [71]. According to meta-analysis conducted by Wang et al. [72], increased consumption of raw fruit and vegetables is associated with lower risk of type 2 diabetes. Other meta-analyses, such as one by Shin et al.[73]did not confirm the association between consumption of fruit and vegetables and fasting plasma glucose. In randomized study conducted by Wallace et al. [74] increased consumption of fruit and vegetables in diet of the obese patients did not significantly altered their insulin sensitivity (during the study the body mass of participants did not change). In the study by Mamluk et al. [75] overall data from NIH-AARP and EPIC Elderly studies showed no association between consumption of fruit and vegetables and incident T2DM. Same authors emphasize however, that there have been large discrepancies between results from cohorts, and in fact, when considering NIH-AARP study alone, there was a significant inverse association between increased intake of fruit and green leafy vegetables and risk of incident diabetes among elderly [75]. In a study by Mursu et al. [76] conducted in men, higher total consumption of fruit, vegetables and especially berries was associated with lower risk of T2DM after mean 19.2 years of follow-up. On the other hand, large prospective study conducted in Chinese women provided an observation, that high consumption of vegetables alone was associated with significantly lower risk of T2DM; for fruit authors found no such association [77]. Particular attention should be paid to legumes, like chickpeas, beans, soybean and lentils, which is a group of vegetables rich in protein and fiber, and characterized by low GI. Evidence from PREDIMED Study [78] indicate, that participants characterized by highest consumption of legumes and lentils had significantly lower risk of developing type 2 diabetes after median 4.3 years of follow-up than participants, who were characterized by lowest consumption of legumes, even after adjusting the analysis for BMI and overall dietary pattern. In a meta-analysis by Jia et al. [79], higher consumption of cruciferous vegetables, but not citrus fruit was associated with significantly lower risk of T2DM. Authors speculated, that characteristic feature of cruciferous vegetables, content of isotiocyanates and indole-3-carbinol can play role in modulating risk of T2DM. As observed in animal studies, isotiocyanates may improve glucose tolerance and signaling [79].

\section{Sugar-sweetened beverages}

According to Singh et al. [80] the consumption of sugar-sweetened beverages (SSB) in high- and upper middle income countries accounts for 0.51 and 0.80 serving/day, respectively (the average intake of SSB was the highest in the age groups of 20-39 years old exceeding 1 serving per/day). The availability of SSB between 1970 and 2005 increased by $19 \%$ in United States [81]. Meta-analysis of 11 prospective cohort studies performed by Malik et al. [82] indicates, that among participants who consumed beverages with added sugar in amounts of 1-2 servings per day, the risk of type 2 diabetes was higher by $26 \%$ in comparison to participants who consumed such beverages only occasionally (less than 1 serving per month). Ma et al. [83] in the analysis of 14 years of observations of Framingham Offspring Cohort study's participants, concluded that increased consumption of sweetened beverages was associated with an increased risk of prediabetes and insulin resistance by $46 \%$ on the contrary to participants, who did not consume such beverages. In the study conducted by Anari et al. [84] consumption of sugar-sweetened beverages was associated with 5-times greater risk of abdominal obesity in diabetic patients, which was associated with increased insulin resistance and increased risk of cardiovascular events. SSB are rich in sucrose or high-fructose corn syrup (HFCS). High consumption of fructose is associated with increased risk of metabolic disorders, increased deposition of fatty acids in the visceral tissue, insulin resistance and glucose metabolism disorders [85].

\section{Nuts}

The association between consumption of nuts and seeds and the risk of type 2 diabetes is difficult to observe, as nuts and seeds differ from one another in terms of nutrients composition. Into this group we can 
include tree nuts, like almonds, hazelnuts, walnuts, cashews, but also legume seeds, like peanuts.

Some studies found an inverse association between the consumption of nuts and risk of type 2 diabetes among adult women[86], but not men [87]. On the other hand, there are meta-analyses, which failed to find an association between nuts consumption and the risk of type 2 diabetes [88]. There are studies investigating the impact of nut consumption on the glycemic control. Meta-analysis of 12 randomized controlled trials [89] concluded that increased consumption of nuts was associated with better glycemic control in type 2 diabetic patients (median dose of $56 \mathrm{~g}$ of nuts per day was associated with lower levels of $\mathrm{HbA} 1 \mathrm{c}$ by $0.07 \%$ and lower fasting glucose level by $0.15 \mathrm{mmol} / \mathrm{L}$ ). Consumption of nuts was associated with lower risk of cardiovascular diseases [90], presumably due to high content of beneficial mono- and polyunsaturated fatty acids as well as active non-nutritive compounds, like polyphenols, which improve oxidative stress and inflammation [91]. Since diabetes increases the risk of cardiovascular complications 2-4-fold [92], it is beneficial to include nuts in the diet. Results of NHANES study provided strong inverse association between consumption of walnuts and T2DM, but what's interesting, the effect was more profound in women than men [93]. Almonds are rich source of MUFA, PUFA, vit. E and minerals: magnesium, calcium, potassium [94]. Some studies show beneficial effect on glucose metabolism after the consumption of almonds: decrease in HbAlc levels [95], lower fasting insulin, fasting glucose and lower HOMA-IR index[96], whereas others fail to find an association between consumption of almonds and fasting glucose and insulin[97]. Walnuts, on the other hand, stand out from other nuts due to very high content of PUFAs (both n-6 and n-3 PUFAs). In two large prospective studies conducted in women in USA, consumption of walnuts was strongly inversely associated with the risk of T2DM, independently of BMI [98]. Peanuts are the richest source of protein among other nuts, they are also the source of MUFAs, PUFAs, potassium and magnesium [99]. In a study by Wien et al. [100] including peanuts into the diet of T2DM participants improved nutritional value of the diet, but did not significantly alter fasting glucose or $\mathrm{HbA} 1 \mathrm{c}$.

\section{CONCLUSION}

There are observations from studies and metaanalyses of an inverse association between consumption of fresh vegetables and fruit, whole grains, lean dairy, fish, nuts and the risk of type 2 diabetes. Food groups that seemed to increase the risk of type 2 diabetes are: red and processed meat, refined grains, sugar-sweetened beverages. It is important to note, that no individual nutrients, but diverse dietary pattern, composed of every recommended food group in adequate amounts can contribute to healthy lifestyle and T2DM prevention.

\section{List of abbreviations}

WHO-World Health Organization; DALYDisability Adjusted Life-Years; T2DM-Type 2 Diabetes Mellitus; GI-Glycemic Index; GL-Glycemic Load; MF\&E- Meat, Fish and Eggs; ADA-American Diabetes Association; OGTT-Oral Glucose Tolerance Test; SFASaturated Fatty Acids; MUFA-Monounsaturated Fatty Acids; PUFA-Polyunsaturated Fatty Acids; HCAsHeterocyclic Amines; SSB-Sugar-sweetened beverages

\section{Ethics Approval and Consent for Participate Not applicable}

\section{Competing interest}

The authors declare no competing interest.

\section{Funding}

Hereby work is funded by Wroclaw Medical University within statutory activity $\mathrm{nr}$ ST.C300.17.005. The funder had no role in the design, analysis or writing of this article.

\section{REFERENCES}

1. World Health Organization. Global Report on Diabetes. Isbn 2016; 978: 88.

2. Schwingshackl L, Georg Hoffmann B, Anna-Maria Lampousi B, et al.: Food groups and risk of type 2 diabetes mellitus: a systematic review and meta-analysis of prospective studies. Eur J Epidemiol; 32. Epub ahead of print 2017. DOI: 10.1007/s10654-017-0246-y.

3. Robertson A, Tirado C, Lobstein T, et al:: Food and health in Europe: a new basis for action. WHO Reg Publ Eur Ser 2004; i-xvi, 1-385, back cover.

4. Meigs JB, Nathan DM, D RB, et al:: Fasting and Postchallenge Glycemia and Cardiovascular Disease Risk The Framingham Offspring Study. Diabetes Care 2002; 25: 1845-50.

5. Emerging Risk Factors Collaboration T. Diabetes mellitus, fasting blood glucose concentration, and risk of vascular disease: a collaborative meta-analysis of 102 prospective studies. Lancet 2010; 375: 2215-2222.

6. Lindst JO, Louheranta A, Mannelin M, et al:. The Finnish Diabetes Prevention Study (DPS) Lifestyle intervention and 3-year results on diet and physical activity FOR THE FINNISH DIABETES PREVENTION STUDY GROUP. Diabetes Care 2003; 26: 3230-6.

7. Cefalu $W$ : American Diabetes Association. Standards of Medical Care in Diabetes - 2016. Diabetes Care; 39. Epub ahead of print 2016. DOI: $10.2337 / \mathrm{dc} 16-\mathrm{S} 001$ Diabetes. 
8. Yao $B$, Fang $H, X u W$, et al.: Dietary fiber intake and risk of type 2 diabetes: a dose-response analysis of prospective studies. Eur J Epidemiol 2014; 29: 79-88.

9. Wirström T, Hilding A, Gu HF et al.: Consumption of whole grain reduces risk of deteriorating glucose tolerance, including progression to prediabetes. $\mathrm{Am} \mathrm{J}$ Clin Nutr 2013; 97: 179-187.

10. Chanson-Rolle A, Meynier A, Aubin F, et al. Systematic Review and Meta-Analysis of Human Studies to Support a Quantitative Recommendation for Whole Grain Intake in Relation to Type 2 Diabetes. PLoS One; 10. Epub ahead of print 2015. DOI: 10.1371/journal.pone.0131377.

11. O'Neil CE, Keast DR, Fulgoni VL, et al. Food sources of energy and nutrients among adults in the US: NHANES 2003-2006. Nutrients 2012; 4: 2097-2120.

12. Nettleton, Jennifer A; McKeown, Nicola M.; Kanoni, Stavroula; Lemaitre, Rozenn N.; Hivert, Marie-France; Ngwa, Julius; van Rooij, Frank J.A.; Sonestedt, Emily; Wojczynski, Mary K.; Ye, Zheng; Tanaka T. Reviews / Commentaries / ADA Statements M E T A - A N A L Y S I S Interactions of Dietary Whole-Grain Intake With Fasting Glucose - and Insulin-Related. Diabetes Care 2010; 33: 2684-2691.

13. Fardet $A$. New hypotheses for the health-protective mechanisms of whole-grain cereals: what is beyond fibre? Epub ahead of print 2017. DOI: 10.1017/ S0954422410000041.

14. Lockyer $S$, Nugent AP. Health effects of resistant starch. Nutr Bull 2017; 42: 10-41.

15. Wong THT, Louie JCY. The relationship between resistant starch and glycemic control: A review on current evidence and possible mechanisms. Starch Stärke 2017; 69: 1600205.

16. Jenkins DJ, Wolever TM, Taylor RH, et al. Glycemic index of foods: a physiological basis for carbohydrate exchange. Am J Clin Nutr 1981; 34: 362-366.

17. Eleazu CO. The concept of low glycemic index and glycemic load foods as panacea for type 2 diabetes mellitus; prospects, challenges and solutions. Afr Health Sci 2016; 16: 468-479.

18. Foster-Powell K, Holt S, Brand-Miller J. International table of glycemic index and glycemic load values: 2002. Am J Clin Nutr 2002; 76: 55-56.

19. Bhupathiraju SN, Tobias DK, Malik VS, et al. Glycemic index, glycemic load, and risk of type 2 diabetes: results from 3 large US cohorts and an updated meta-analysis 1-3. Am J Clin Nutr 2014; 100: 218-32.

20. Krishnan S, Rosenberg L, Singer $M$, et al. Glycemic Index, Glycemic Load, and Cereal Fiber Intake and Risk of Type 2 Diabetes in US Black Women. Arch Intern Med 2007; 167: 2304.

21. Villegas R, Liu S, Gao Y-T, et al. Prospective Study of Dietary Carbohydrates, Glycemic Index, Glycemic Load, and Incidence of Type 2 Diabetes Mellitus in Middle-aged Chinese Women. Arch Intern Med 2007; 167: 2310 .
22. Similä ME, Valsta LM, Kontto JP, et al. Low-, mediumand high-glycaemic index carbohydrates and risk of type 2 diabetes in men. Br J Nutr 2011; 105: 1258-64.

23. Jenkins DJA, Kendall CWC, McKeown-Eyssen G, et al. Effect of a Low-Glycemic Index or a High-Cereal Fiber Diet on Type 2 Diabetes. JAMA 2008; 300: 2742.

24. Gomes JMG, Fabrini SP, Alfenas $R$ de CG. Low glycemic index diet reduces body fat and attenuates inflammatory and metabolic responses in patients with type 2 diabetes. Arch Endocrinol Metab 2017; 61: 137 144.

25. Ma Y, Olendzki BC, Merriam $P A$, et al. A randomized clinical trial comparing low-glycemic index versus ADA dietary education among individuals with type 2 diabetes. Nutrition 2008; 24: 45-56.

26. Tong $X$, Dong $J-Y, W u Z-W$, et al. Dairy consumption and risk of type 2 diabetes mellitus: a meta-analysis of cohort studies. Eur J Clin Nutr 2011; 65: 1027-103162.

27. Pittas AG, Lau J, Hu F, et al. The Role of Vitamin D and Calcium in type 2 diabetes. A systematic Review and Meta-Analysis *. J Clin Endocrinol Metab 2007; 92: 2017-2029.

28. Liu S, Choi HK, Ford E, et al. A Prospective Study of Dairy Intake and the Risk of Type 2 Diabetes in Women. Diabetes Care 2006; 29: 1579-84.

29. Pal $S$, Ellis $V$, Dhaliwal S. Effects of whey protein isolate on body composition, lipids, insulin and glucose in overweight and obese individuals. Br J Nutr 2010; 104: 716-723.

30. Ryan AT, Feinle-Bisset $C$, Kallas A, et al. Intraduodenal protein modulates antropyloroduodenal motility, hormone release, glycemia, appetite, and energy intake in lean men. Am J Clin Nutr 2012; 96: 474-82.

31. Malik VS, Sun Q, Van Dam RM, et al. Adolescent dairy product consumption and risk of type 2 diabetes in middle-aged women 1-3. Am J Clin Nutr 2011; 94: 854-61.

32. Sluijs I, Forouhi NG, Beulens JW, et al. The amount and type of dairy product intake and incident type 2 diabetes: results from the EPIC-InterAct Study 1-3. Am J Clin Nutr 2012; 96: 382-90.

33. Chen M, Sun Q, Giovannucci E, et al. Dairy consumption and risk of type 2 diabetes: 3 cohorts of US adults and an updated meta-analysis. Epub ahead of print 2014 DOI: 10.1186/s12916-014-0215-1.

34. Fernandez MA, Marette A. Potential Health Benefits of Combining Yogurt and Fruits Based on Their Probiotic and Prebiotic Properties 1-3. Adv Nutr 2017; 8: $155 \mathrm{~S}-164 \mathrm{~S}$.

35. Kassaian N, Feizi A, Ashraf Aminorroaya, et al. The effects of probiotics and synbiotic supplementation on glucose and insulin metabolism in adults with prediabetes: a double-blind randomized clinical trial. Acta Diabetol 2018; 55: 1019-1028.

36. Jarosz M. Nutritional Guidelines for Polish Population (Normy żywienia dla populacji Polski). Warszawa: 
Instytut Żywności i Żywienia, http://zywnosc.com. pl/wp-content/uploads/2017/12/normy-zywienia-dlapopulacji-polski-2017-1.pdf (2017, accessed 2 March 2018).

37. United States Department of Agriculture and Department of Health and Human Services. 2015 - 2020 Dietary Guidelines for Americans. Washington. Epub ahead of print 2015. DOI: 10.1097/NT.0b013e31826c50af.

38. Jackie Boucher and L, Evert AB, Boucher JL, et al. Nutrition Therapy Recommendations for the Management of Adults With Diabetes. Diabetes Care; 37. Epub ahead of print 2014. DOI: 10.2337/dc14-S120.

39. Ke Q, Chen $\mathrm{C}, \mathrm{He} \mathrm{F}$, et al. Association between dietary protein intake and type 2 diabetes varies by dietary pattern. Diabetol Metab Syndr 2018; 10: 48.

40. Feskens EJM, Sluik D, Van Woudenbergh GJ. Meat consumption, diabetes, and its complications. Curr Diab Rep 2013; 13: 298-306.

41. Kim Y, Keogh JB, Clifton PM. Consumption of red and processed meat and refined grains for 4 weeks decreases insulin sensitivity in insulin-resistant adults: a randomized crossover study. Metabolism 2016; 68: 173-183.

42. Zelber-Sagi S, Ivancovsky-Wajcman D, Fliss $N$, et al. High red and processed meat consumption is associated with non-alcoholic fatty liver disease and insulin resistance. J Hepatol 2018; 68: 1239-1246.

43. Liu S, Van Der Schouw YT, Sabita, et al. Intake of dietary saturated fatty acids and risk of type 2 diabetes in the European Prospective Investigation into Cancer and Nutrition-Netherlands cohort: associations by types, sources of fatty acids and substitution by macronutrients. Eur J Nutr. Epub ahead of print 2018. DOI: 10.1007/s00394-018-1630-4.

44. Baghdasarian S, Lin H-P, Pickering R, et al. Dietary Cholesterol Intake Is Not Associated with Risk of Type 2 Diabetes in the Framingham Offspring Study. Nutrients 2018; 10: 665.

45. Guess N, Perreault L, Kerege A, et al. Dietary Fatty Acids Differentially Associate with Fasting Versus 2-Hour Glucose Homeostasis: Implications for The Management of Subtypes of Prediabetes. Epub ahead of print 2016. DOI: 10.1371/journal.pone.0150148.

46. Wanders AJ, Alssema M, De Koning E, et al. Fatty acid intake and its dietary sources in relation with markers of type 2 diabetes risk: The NEO study. Eur J Clin Nutr 2016; 71: 245-251.

47. Fernandez-Real JM, McClain D, Manco M. Mechanisms Linking Glucose Homeostasis and Iron Metabolism Toward the Onset and Progression of Type 2 Diabetes. Diabetes Care 2015; 38: 2169-2176.

48. de la Monte SM, Tong M, Lawton M, et al. Nitrosamine exposure exacerbates high fat diet-mediated type 2 diabetes mellitus, non-alcoholic steatohepatitis, and neurodegeneration with cognitive impairment. Mol Neurodegener 2009; 4: 54.
49. Micha R, Michas $G$, Mozaffarian D. Unprocessed red and processed meats and risk of coronary artery disease and type 2 diabetes--an updated review of the evidence. Curr Atheroscler Rep 2012; 14: 515-24.

50. Liu G, Zong G, Wu K, et al. Meat Cooking Methods and Risk of Type 2 Diabetes: Results From Three Prospective Cohort Studies. Diabetes Care 2018; 41: 1049-1060.

51. Kim Y-S, Xun P, Iribarren $C$, et al. Intake of fish and long-chain omega-3 polyunsaturated fatty acids and incidence of metabolic syndrome among American young adults: a 25-year follow-up study. Eur J Nutr 2016; 55: 1707-16.

52. Rylander $C$, Sandanger TM, Engeset $D$, et al. Consumption of Lean Fish Reduces the Risk of Type 2 Diabetes Mellitus: A Prospective Population Based Cohort Study of Norwegian Women. PLoS One; 9. Epub ahead of print 2014. DOI: 10.1371/journal. pone.0089845.

53. Chua J, Chia A-R, Chee $M L$, et al. The relationship of dietary fish intake to diabetic retinopathy and retinal vascular caliber in patients with type 2 diabetes. Sci Rep 2018; 8: 730.

54. Mirmiran P, Esfandyari S, Moghadam SK, et al. Fatty acid quality and quantity of diet and risk of type 2 diabetes in adults: Tehran Lipid and Glucose Study. J Diabetes Complications 2018; 32: 655-659.

55. O'mahoney LL, Matu J, Price OJ, et al. Omega-3 polyunsaturated fatty acids favourably modulate cardiometabolic biomarkers in type 2 diabetes: a metaanalysis and meta-regression of randomized controlled trials. Cardiovasc Diabetol 2018; 17: 98.

56. Wu JH, Micha R, Imamura F, et al. Omega-3 Fatty Acids and incident Type 2 Diabetes: A Systematic Review and Meta-Analysis. Br J Nutr 2012; 107: 214-21.

57. Chen $C, Y u X$, Shao $S$. Effects of Omega-3 Fatty Acid Supplementation on Glucose Control and Lipid Levels in Type 2 Diabetes: A Meta-Analysis. Epub ahead of print 2015. DOI: 10.1371/journal.pone.0139565.

58. Abbott KA, Burrows TL, Thota RN, et al. Do -3 PUFAs affect insulin resistance in a sex-specific manner? A systematic review and meta-analysis of randomized controlled trials. Am J Clin Nutr 2016; 104: 1470-1484.

59. Tamez M, Virtanen JK, Lajous M. Egg consumption and risk of incident type 2 diabetes: a dose-response metaanalysis of prospective cohort studies. Br J Nutr 2016; 115: 2212-8.

60. Wallin A, Forouhi N, Wolk A, et al. Egg consumption and risk of type 2 diabetes: a prospective study and dose-response meta-analysis. Diabetologia 2016; 59: 1204-13.

61. Jarosz J.: Normy żywienia dla populacji polskiej-nowelizacja, http:/www.izz.waw.pl/attachments/article/33/NormyZywieniaNowelizacjaIZZ2012.pdf (2012, accessed 25 March 2017). 
62. Wani TA, Masoodi FA, Gani A, et al. Olive oil and its principal bioactive compound_Hydroxytyrosol - A review of the recent literature. Epub ahead of print 2018. DOI: 10.1016/j.tifs.2018.05.001.

63. Jemai H, El Feki A, Sayadi S. Antidiabetic and Antioxidant Effects of Hydroxytyrosol and Oleuropein from Olive Leaves in Alloxan-Diabetic Rats. J Agric Food Chem 2009; 57: 8798-8804.

64. Giugliano JA, Goudevenos DB, Panagiotakos C-M, et al. The Effect of Mediterranean Diet on Metabolic Syndrome and its Components: The Effect of Mediterranean Diet on Metabolic Syndrome and its Components. JAC 2011; 57: 1299-1313.

65. Guasch-Ferré M, Hruby A, Salas-Salvadó J, et al. Olive oil consumption and risk of type 2 diabetes in US women 1-3. Am J Clin Nutr 2015; 102: 479-86.

66. Orsavova J, Misurcova L, Ambrozova JV, et al. Fatty Acids Composition of Vegetable Oils and Its Contribution to Dietary Energy Intake and Dependence of Cardiovascular Mortality on Dietary Intake of Fatty Acids. Int J Mol Sci 2015; 16: 12871-90.

67. Nigam P, Bhatt S, Misra A, et al. Effect of a 6-Month Intervention with Cooking Oils Containing a High Concentration of Monounsaturated Fatty Acids (Olive and Canola Oils) Compared with Control Oil in Male Asian Indians with Nonalcoholic Fatty Liver Disease. Diabetes Technol Ther 2014; 16: 255-261.

68. Goyal A, Sharma V, Upadhyay N, et al. Flax and flaxseed oil: an ancient medicine \&amp; modern functional food. J Food Sci Technol 2014; 51: 1633-1653.

69. Bloedon LT, Balikai S, Chittams J, et al. Flaxseed and cardiovascular risk factors: results from a double blind, randomized, controlled clinical trial. J Am Coll Nutr 2008; 27: 65-74.

70. Sotoudeh $G$, Abshirini M, Student MSPH, et al. Higher dietary total antioxidant capacity is inversely related to prediabetes: A case-control study. Nutrition 2018; 46: 20-25.

71. Rienks J, Barbaresko J, Oluwagbemigun $K$, et al. Polyphenol exposure and risk of type 2 diabetes: doseresponse meta-analyses and systematic review of prospective cohort studies. Am J Clin Nutr 2018; 108: 49-61.

72. Wang PY, Fang JC, Gao ZH, et al. Higher intake of fruits, vegetables or their fiber reduces the risk of type 2 diabetes: A meta-analysis. J Diabetes Investig 2016; 7: 56-69.

73. Shin JY, Kim JY, Kang HT, et al. Effect of fruits and vegetables on metabolic syndrome: a systematic review and meta-analysis of randomized controlled trials. Int $\mathrm{J}$ Food Sci Nutr 2015; 66: 416-425.

74. Wallace IR, Mcevoy CT, Hunter SJ, et al. DoseResponse Effect of Fruit and Vegetables on Insulin Resistance in People at High Risk of Cardiovascular Disease A randomized controlled trial. Diabetes Care 2013; 36: 3888-96.
75. Mamluk L, O'Doherty MG, Orfanos $P$, et al. Fruit and vegetable intake and risk of incident of type 2 diabetes: results from the consortium on health and ageing network of cohorts in Europe and the United States (CHANCES). Eur J Clin Nutr 2017; 71: 83-91.

76. Mursu J, Virtanen JK, Tuomainen T-P, et al. Intake of fruit, berries, and vegetables and risk of type 2 diabetes in Finnish men: the Kuopio Ischaemic Heart Disease Risk Factor Study. Am J Clin Nutr 2014; 99: 328-333.

77. Villegas $R$, Shu XO, Gao Y-T, et al. Vegetable but Not Fruit Consumption Reduces the Risk of Type 2 Diabetes in Chinese Women. J Nutr 2008; 138: 574-580.

78. Becerra-Tom as N, es Díaz-Lopez A, Rosique-Esteban N, et al. Legume consumption is inversely associated with type 2 diabetes incidence in adults: A prospective assessment from the PREDIMED study. Epub ahead of print 2018. DOI: 10.1016/j.clnu.2017.03.015.

79. Jia X, Zhong L, Song Y, et al. Consumption of citrus and cruciferous vegetables with incident type 2 diabetes mellitus based on a meta-analysis of prospective study. Epub ahead of print 2016. DOI: 10.1016/j. pcd.2015.12.004.

80. Singh GM, Micha $R$, Khatibzadeh S, et al. Global, Regional, and National Consumption of SugarSweetened Beverages, Fruit Juices, and Milk: A Systematic Assessment of Beverage Intake in 187 Countries. PLoS One; 10. Epub ahead of print 2015. DOI: http://dx.doi.org/10.1371/journal. pone.0124845.

81. Johnson RK, Appel LJ, Brands M, et al. Dietary sugars intake and cardiovascular health: a scientific statement from the American Heart Association. Circulation 2009; 120: 1011-20.

82. Malik VS, Popkin BM, Bray GA, et al. Sugar-Sweetened Beverages and Risk of Metabolic Syndrome and Type 2 Diabetes. Diabetes Care 2010; 33: 2477-83.

83. Ma J, Jacques PF, Meigs JB, et al. Sugar-Sweetened Beverage but Not Diet Soda Consumption Is Positively Associated with Progression of Insulin Resistance and Prediabetes. J Nutr 2016; 146: 2544-2550.

84. Anari R, Amani R, Veissi M. Sugar-sweetened beverages consumption is associated with abdominal obesity risk in diabetic patients. Diabetes Metab Syndr Clin Res Rev. Epub ahead of print 2017. DOI: 10.1016/j. dsx.2017.04.024.

85. Stanhope KL, Schwarz JM, Keim NL, et al. Consuming fructose-sweetened, not glucose- sweetened, beverages increases visceral adiposity and lipids and decreases insulin sensitivity in overweight/obese humans. 119. Epub ahead of print 2009. DOI: 10.1172/JCI37385.

86. Jiang R, Manson JE, Stampfer MJ, et al. Nut and Peanut Butter Consumption and Risk of Type 2 Diabetes in Women. JAMA 2002; 288: 2554.

87. Kochar J, Gaziano JM, Djoussé L. Nut Consumption and Risk of Type 2 Diabetes in the Physicians' Health Study. Eur J Clin Nutr 2010; 64: 75-9. 
88. Wu L, Wang Z, Zhu J, et al. Nut consumption and risk of cancer and type 2 diabetes: a systematic review and meta-analysis. Nutr Rev V R 2015; 73: 409-425.

89. Viguiliouk E, Kendall CWC, Mejia SB, et al. Effect of Tree Nuts on Glycemic Control in Diabetes: A Systematic Review and Meta-Analysis of Randomized Controlled Dietary Trials. PLoS One; 9. Epub ahead of print 2014. DOI: 10.1371/journal.pone.0103376.

90. Zhou D, Yu H, He F, et al. Nut consumption in relation to cardiovascular disease risk and type 2 diabetes: a systematic review and meta-analysis of prospective studies. Am J Clin Nutr 2014; 100: 270-7.

91. Kim Y, Keogh JB, Clifton PM. Benefits of nut consumption on insulin resistance and cardiovascular risk factors: Multiple potential mechanisms of actions. Nutrients; 9. Epub ahead of print 2017. DOI: 10.3390/ nu9111271.

92. Kirpichnikov D, Sowers JR. Diabetes mellitus and diabetes-associated vascular disease. Trends Endocrinol Metab 2001; 12: 225-30.

93. Arab L, Dhaliwal SK, Martin CJ, et al. Association between walnut consumption and diabetes risk in NHANES. Diabetes Metab Res Rev 2018; 1-8.

94. Kalita S, Khandelwal S, Madan J, et al. Almonds and Cardiovascular Health: A Review. Nutrients; 10. Epub ahead of print 11 April 2018. DOI: 10.3390/ nu10040468.
95. Chen $C-M$, Liu $J-F$, Li $S-C$, et al. Almonds ameliorate glycemic control in Chinese patients with better controlled type 2 diabetes: a randomized, crossover, controlled feeding trial. Nutr Metab (Lond) 2017; 14: 51.

96. Li S-C, Liu Y-H, Liu J-F, et al. Almond consumption improved glycemic control and lipid profiles in patients with type 2 diabetes mellitus. Metabolism 2011; 60: 474-479.

97. Jenkins DJA, Kendall CWC, Marchie A, et al. Effect of almonds on insulin secretion and insulin resistance in nondiabetic hyperlipidemic subjects: a randomized controlled crossover trial. Metabolism 2008; 57: 882887.

98. Pan A, Sun $Q$, Manson JE, et al. Walnut consumption is associated with lower risk of type 2 diabetes in women. J Nutr 2013; 143: 512-8.

99. Arya SS, Salve AR, Chauhan S. Peanuts as functional food: a review. J Food Sci Technol 2016; 53: 31-41.

100. Wien M, Oda K, Sabaté J. A randomized controlled trial to evaluate the effect of incorporating peanuts into an American Diabetes Association meal plan on the nutrient profile of the total diet and cardiometabolic parameters of adults with type 2 diabetes. Nutr J 2014; 13: 10 .

Received: 15.06 .2019

Accepted: 14.09.2019 